Article

\title{
Reuse of Dunite Mining Waste and Subproducts for the Stabilization of Metal(oid)s in Polluted Soils
}

\author{
Diego Baragaño ${ }^{1, *}$, Rubén Forján ${ }^{1}\left[\mathbb{D}\right.$, Juan María Menéndez Aguado ${ }^{2}$, Marcos Covián Martino ${ }^{3}$, \\ Pamela Díaz García ${ }^{3}$, Javier Martínez Rubio ${ }^{3}$, Juan José Álvarez Rueda ${ }^{3}$ \\ and José Luis R. Gallego ${ }^{1}$ (D) \\ 1 INDUROT and Environmental Technology, Biotechnology and Geochemistry Group, Campus de Mieres, \\ Universidad de Oviedo, 33600 Mieres, Asturias, Spain \\ 2 Polytechnic School of Mieres, University of Oviedo, 33003 Oviedo, Asturias, Spain \\ 3 Pasek Minerales, SAU. Mina Dunita Landoy, 15360 Cariño, A Coruña, Spain \\ * Correspondence: diegobcoto@uniovi.es; Tel.: +34-98-545-8203
}

Received: 16 July 2019; Accepted: 6 August 2019; Published: 8 August 2019

\begin{abstract}
The circular economy seeks to minimize the use of raw materials and waste generation. In this context, here we addressed the use of dunite mining tailings and subproducts to stabilize metal(oid)s in polluted soils. We first characterized the dunite mining tailings and subproducts, and a paradigmatic polluted soil in depth to determine their chemical and mineralogical properties. Experimental trials using Brassica juncea L. were performed to evaluate the impact of the two materials on vegetation growth, edaphic properties and pollutant stabilization yields. To this end, the plants were grown over 75 days in $1 \mathrm{~kg}$ pots containing the polluted soil amended with the dunite materials. Notably, both amendments caused a dramatic decrease in the available $\mathrm{Zn}$ and a moderate reduction in available $\mathrm{Cu}, \mathrm{Cd}$ and $\mathrm{Pb}$. In contrast, the concentration of available As was not modified. The cation exchange capacity (CEC) was improved by treatment with the amendments, allowing an increase in the biomass harvested. The immobilization mechanism achieved was probably due to an increase in $\mathrm{pH}$ and CEC. In conclusion, the dunite tailings and subproducts could be effective amendments for stabilizing polluted soil. This work paves the way for additional studies with distinct types of soils and conditions.
\end{abstract}

Keywords: dunite; soil; stabilization; metal(oid)s; mining

\section{Introduction}

The massive production of waste is one of the most pressing problems faced by society today [1,2]. In this regard, human consumption and production practices are having a detrimental effect on environmental quality, social equity and long-term economic stability [3-5]. In response to this issue, governments currently focus their policies on the circular economy [6,7], which has been proposed as an effective model through which to decrease the generation of waste and minimize the use of raw material, thereby achieving sustainable development [8].

Mineral production continues to be necessary for economic development. However, mining and ore processing generate large amounts of soil and liquid materials that are classified as waste [9]. Consequently, the management of mining and mineral-processing waste also raises concerns in terms of recycling and economic strategies for the future [10]. These waste products are generally harmful for environmental compartments because they contain high concentrations of potentially toxic elements [11], thus ruling out their reuse and generating the need for appropriate management. Mine waste is characterized by null edaphological properties [12] and it can often become an environmental concern since it may leach toxic elements such as heavy metal(loid)s [13-15]. However, some 
non-hazardous mine wastes can be recycled as a result of their properties. In this context, such waste can, for instance, be used to reduce the available concentrations of metals in soils, thereby closing the cycle of the circular economy with zero or almost zero waste [16,17]. Well-known examples of this approach are magnesium oxide- [18] and lime-enriched waste [19], which have been used for soil remediation purposes.

In this context, given that dunite waste and subproducts are potential positive soil amendments due to their composition (mainly magnesium oxide and lime), here we evaluated the capacity of these materials to stabilize metal(oid)s in polluted soils and thus to reduce the potential leaching of contaminants. In addition, the use of $\mathrm{Mg}$ amendments may improve soil properties from a plant perspective. Therefore, the objectives of this study were to (a) address the potential properties of dunite waste and subproducts in order to stabilize a metal(oid)s polluted soil, (b) to improve the soil properties, and (c) to evaluate the reduction or increase of toxicity in a plant species focusing on the biomass production.

\section{Material and Methods}

\subsection{Polluted Soil Sampling}

A bulk sample of $20 \mathrm{~kg}$ of a polluted soil (labeled W) from a brownfield (Spain, 43.3138854W, $-5.7003794 \mathrm{~N}$ ) affected by multi-element pollution was used for the experiments. Before use, the sample was air-dried and sieved through a $2-\mathrm{mm}$ mesh. Regarding the soil properties, the $\mathrm{pH}$ and electrical conductivity (EC) were measured in suspension using a 1:2.5 (w/v) ratio of soil and deionized water [20]. Total soil carbon (TC) and total nitrogen (TN) were determined in a LECO CN-2000 module using solid samples. Available concentrations of metals were measured by means of TCLP extraction (toxicity characteristic leaching procedure) following USEPA Method 1311 (1992). Pseudo-total metal contents were extracted with aqua regia by acid digestion in a microwave oven (Milestone ETHOS 1 , Bergamo, Italy). Metal concentrations were determined by ICP-OES (Optima 4300 DV; Perkin-Elmer, Massachusetts, U.S.). Exchangeable cations $\left(\mathrm{Ca}^{2+}, \mathrm{K}^{+}, \mathrm{Mg}^{2+}, \mathrm{Na}^{+}\right.$, and $\left.\mathrm{Al}^{3+}\right)$ were extracted with 0.1 $\mathrm{M} \mathrm{BaCl}_{2}$ [21] and element concentrations were measured by ICP-OES (Perkin-Elmer Optima 4300 DV). Effective cation exchange capacity (CEC) was determined by the sum of exchangeable cation concentrations [22]. Available phosphorus was determined by the Mehlich method [23].

\subsection{Amendments}

Amendments for this study were taken from the processing plant in the only dunite mine in Spain, the David Mine, in Landoi (Galicia, 43.6981867W, -7.9268375N). The quarry of this mine is owned and operated by Pasek Minerals. Strictly speaking, the mined rock cannot be classified as dunite because it does not contain the required $90 \%$ olivine content. Its high orthopyroxene content allows it to be classified as a peridotite or more precisely harzburgite [24,25]. However, because of its high olivine content (see below) the commercial name of the product is dunite.

A variety of minerals can be identified in the rock exploited in this quarry, with some variation range due to geological changes, but the most common minerals are olivine $(20 \%-35 \%)$, orthopyroxene $(8 \%-16 \%)$, amphibole $(14 \%-20 \%)$, and crisotile $(0 \%-33 \%)$, whereas amorphous phases usually range from $5 \%$ to $30 \%$ [26]. In some areas of the quarry where weathering and hydrothermal alterations took place, minerals, such as clays, serpentine and chlorite, can also be found. The presence of these minerals is usually undesired since they accumulate in the fine fraction as a result of the blasting process. Therefore wet scalping of the feed to the primary crusher is then required, as explained below.

After blasting operations, the material with a grain size $<1250 \mathrm{~mm}$ passes through several stages of crushing, screening and milling (Figure 1). The processing starts at the feeder, which ensures a constant feed rate to the scalper. At the scalper, the fine particles are washed out and the larger particles $(>20 \mathrm{~mm})$ are directed to the primary crusher. This jaw crusher is adjusted to achieve a product below $200 \mathrm{~mm}$. Scalped fine particles are further processed by wet screening and hydrocycloning, 
and different size fractions are recovered separately. However, the mineralogy of this fine product is not usually suitable for most current applications, so it is used as landfill, while the finest fractions ( $<63$ microns) are stored in the tailings dam. In this context, the waste used in this study, called "dunite-tailings" (labeled DT) was taken from the hydrocyclone spigot product.

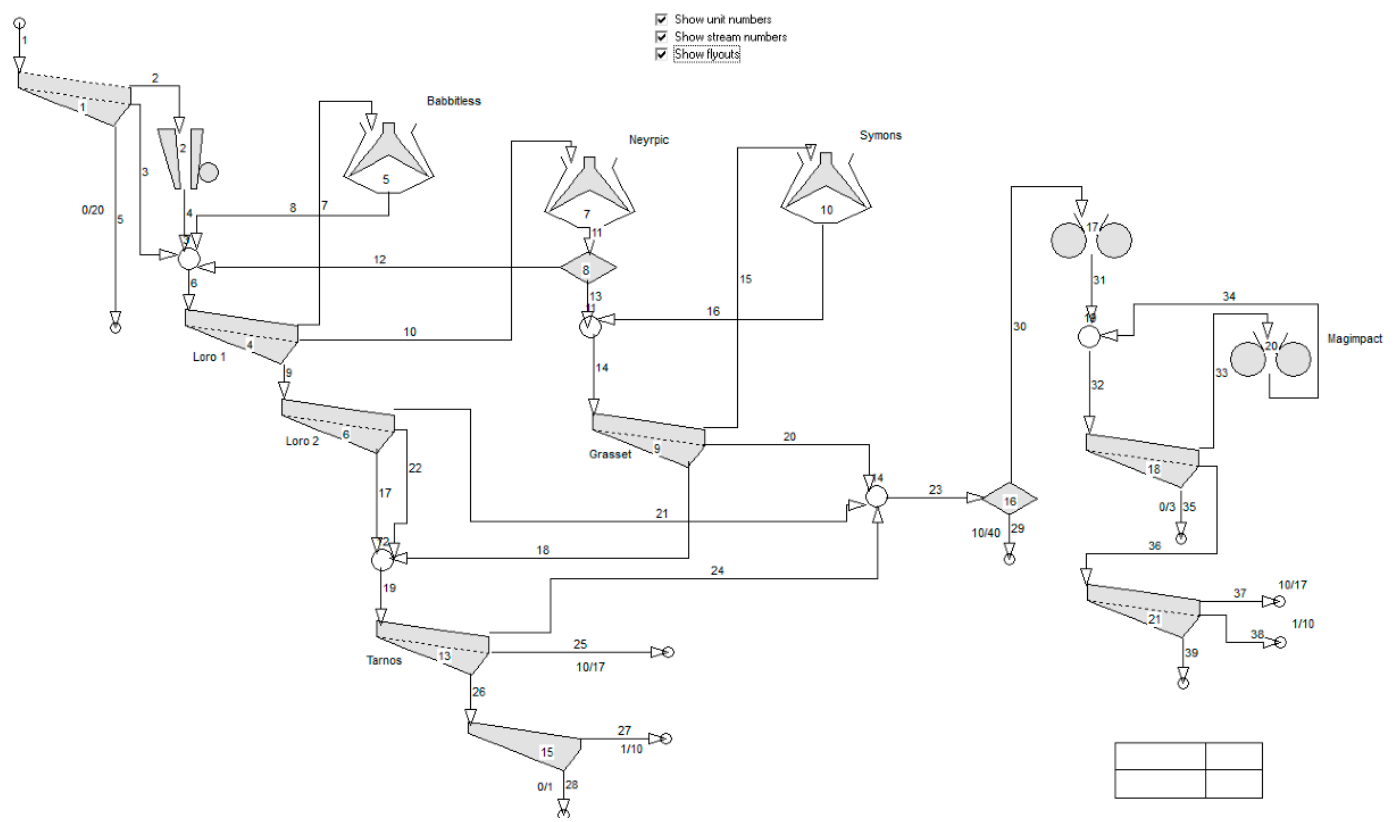

Figure 1. Flow diagram of the David Mine plant (screen capture of MODSIM 3.6).

Regarding the primary crushed product (0-200 $\mathrm{mm}$ particle size), this material is treated in the following stages of the processing plant, generating several products, which are commercialized by the company. The other sample used in this study, called "dunite-comminuted" (labeled DC) corresponds to a product with a particle size of $0-1 \mathrm{~mm}$.

The properties of DT and DC were determined following the same methodology used for the characterization of the polluted soil described above. Additionally, the mineralogical composition of DT was determined on the basis of powder X-ray diffraction (PXRD) patterns, measured on a Philips X'Pert Pro X-ray diffractometer with $\mathrm{Cu} \mathrm{k} \alpha 1$ radiation (1.540598 $\AA$ ). After determining the position of Bragg peaks over the range of $2=5-90^{\circ}$, the minerals were identified using databases of the International Centre for Diffraction Data. In addition, chemical composition was determined using a Philips PW 2404 X-ray fluorescence (XRF) apparatus.

The DC had the same composition as the dunite studied by [26], and this was checked by XRF.

\subsection{Greenhouse Experiment}

The experiment, which involved the use of plant pots, was carried out in a greenhouse for 75 days (Figure 2). The greenhouse was maintained at an average temperature of $13 \pm 4{ }^{\circ} \mathrm{C}$ and a humidity of $75 \pm 3 \%$, replicating usual weather conditions of a brownfield site. The conditions for the experiments were as indicated in Table 1.

The total weight of each pot was $1 \mathrm{~kg}$. Initially, the dunite amendments were thoroughly mixed with the soil in the pots. Pots were watered 3 days per week with drop water up to holding water capacity. Pots containing the polluted soil not treated with the amendments were used as controls (W), (Table 1). The pots containing treated soil were initially incubated for 7 days. Later, Brassica juncea L. seeds were pre-germinated in seedbeds until 2 fully expanded leaves had grown. The plants were then transferred to the pots. The plants were harvested at the same stage of maturity (pre-flowering state) to facilitate comparison of development. 


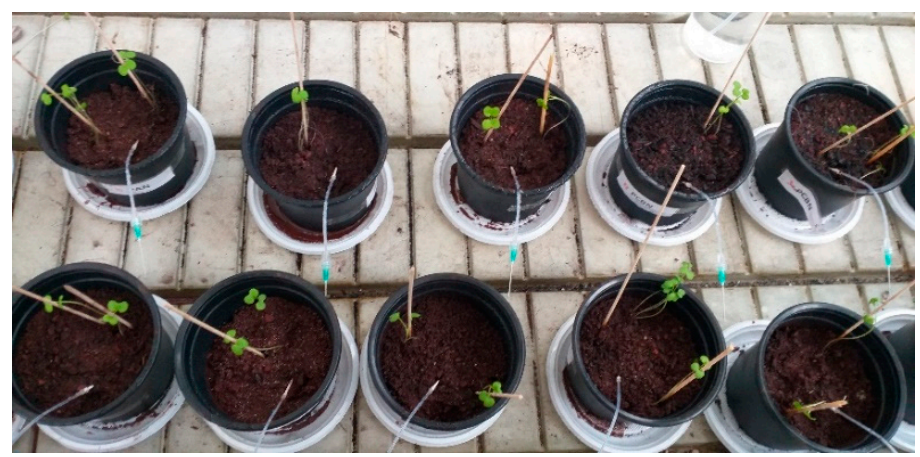

Figure 2. Pot design with the Brassica juncea L. plants.

Table 1. Proportions of soil and amendments used in the treatments. W, untreated soil; WDT, soil treated with dunite-tailings; WDC, soil treated with dunite comminuted.

\begin{tabular}{ccccc}
\hline Code & Polluted Soil & Dunite-Tailings & Dunite-Comminuted & Brassica juncea $\mathbf{L}$. \\
\hline W & $100 \%$ & & & yes \\
WDT & $80 \%$ & $20 \%$ & $20 \%$ & yes \\
WDC & $80 \%$ & & yes \\
\hline
\end{tabular}

W: untreated soil; WDT: soil treated with dunite-tailings; WDC: soil treated with dunite comminuted.

After the experiment, the soil samples were air dried, sieved through a 2-mm mesh, and homogenized for the analytical procedures. The same analysis as that done during characterization of the polluted soil was performed (see Section 2.1). Regarding Brassica juncea L., they were carefully washed with deionized water. Fresh biomass was immediately weighed, and dry mass was assessed after oven-drying for $48 \mathrm{~h}$ at $80^{\circ} \mathrm{C}$ and then cooling at room temperature.

\subsection{Statistical Analysis}

All analytical determinations were performed in triplicate. The data obtained were treated using the SPSS program, version 19.0 for Windows. Analysis of variance (ANOVA) and test of homogeneity of variance were carried out. In the case of homogeneity, a post hoc least significant difference (LSD) test was carried out. If there was no homogeneity, Dunnett's T3 test was performed. A correlated bivariate analysis was also performed by means of Pearson correlation.

\section{Results}

\subsection{Properties of the Soil and Amendments}

The characterization of the polluted soil (W) and the two amendments, dunite-tailings (DT) and dunite-comminuted (DC), is summarized in Table 2.

The data revealed high pseudo-total concentrations of the metal(oid)s of interest, although the main pollutant with a high available concentration was $\mathrm{Zn}$. With respect to edaphic characteristics, the soil was found to be alkaline and to contain a very low nutrient content.

The DC composition revealed a high $\mathrm{MgO}$ and $\mathrm{SiO}_{2}$ content due to the presence of forsterite, olivine and serpentine [26]. However, the amendment also contained $\mathrm{Al}_{2} \mathrm{O}_{3}, \mathrm{CaO}$ and $\mathrm{Fe}_{2} \mathrm{O}_{3}$ (Table 3). In contrast, the dunite-tailings (DT) presented a higher concentration of $\mathrm{SiO}_{2}$ and lower concentration of $\mathrm{MgO}$. However, a notable difference with respect to $\mathrm{DC}$ was the slight increase in $\mathrm{CaO}$ concentration, which could be a relevant parameter for remediation. From the point of view of mineralogy, the diffraction pattern (Figure 3) showed that DT was composed mainly of minerals from the serpentine group (lizardite) and chlorite group (clinochlore and kammererite). Hornblende and ankerite may have been present in low concentrations. The mineral composition of the two amendments was consistent with the chemical data obtained by XRF. 
Table 2. Characteristics and metal concentrations of polluted soil (W), dunite-comminuted (DC) and dunite-tailings (DT).

\begin{tabular}{|c|c|c|c|c|c|}
\hline \multirow{2}{*}{\multicolumn{2}{|c|}{ Parameters }} & \multirow{2}{*}{ Units } & \multicolumn{3}{|c|}{ Samples } \\
\hline & & & $\mathbf{W}$ & DT & DC \\
\hline \multirow{9}{*}{ Edaphic } & $\mathrm{pH}$ & & 7.99 & 9.23 & 9.16 \\
\hline & TC & \multirow{7}{*}{$\mathrm{mg} \cdot \mathrm{kg}^{-1}$} & 23.10 & 5.31 & 2.20 \\
\hline & TN & & $<\mathrm{DL}$ & $<\mathrm{DL}$ & $<\mathrm{DL}$ \\
\hline & $\mathbf{P}$ & & 3.14 & 2.21 & $<2.00$ \\
\hline & K & & 25.75 & 78.60 & 42.55 \\
\hline & $\mathrm{Mg}$ & & 27.17 & 577.70 & 672.50 \\
\hline & $\mathrm{Ca}$ & & 466.70 & 120.10 & 143.90 \\
\hline & $\mathrm{Na}$ & & 3.09 & 20.99 & 24.70 \\
\hline & CEC & $\mathrm{cmol}_{(+)} \cdot \mathrm{kg}^{-1}$ & 5.30 & 11.30 & 13.00 \\
\hline \multirow{5}{*}{$\begin{array}{l}\text { Pseudo-total } \\
\text { concentration }\end{array}$} & $\mathrm{Cu}$ & \multirow{5}{*}{$\mathrm{mg} \cdot \mathrm{kg}^{-1}$} & 1707.80 & 28.78 & 33.84 \\
\hline & Zn & & 3739.50 & 37.63 & 261.6 \\
\hline & $\mathrm{Cd}$ & & 24.61 & 0.89 & 2.53 \\
\hline & As & & 632.40 & 15.94 & 4.04 \\
\hline & $\mathrm{Pb}$ & & 5112.20 & 17.71 & 47.98 \\
\hline \multirow{5}{*}{$\begin{array}{c}\text { Available } \\
\text { concentration }\end{array}$} & $\mathrm{Cu}$ & \multirow{5}{*}{$\mathrm{mg} \cdot \mathrm{kg}^{-1}$} & 4.70 & $<\mathrm{DL}$ & 0.15 \\
\hline & Zn & & 176.54 & $<\mathrm{DL}$ & 47.41 \\
\hline & $\mathrm{Cd}$ & & 0.67 & $<\mathrm{DL}$ & 1.03 \\
\hline & As & & 0.32 & $<\mathrm{DL}$ & 0.09 \\
\hline & $\mathrm{Pb}$ & & 24.63 & 0.06 & 2.09 \\
\hline
\end{tabular}

Values $(\mathrm{n}=3)$. <DL: below detection limit; TN: total nitrogen; TC: total carbon; P: available phosphorus (Mehlich).

Table 3. X-ray fluorescence (XRF) composition of the two amendments.

\begin{tabular}{ccccccccc}
\hline Amendment & $\mathrm{SiO}_{\mathbf{2}}$ & $\mathrm{Al}_{\mathbf{2}} \mathbf{O}_{\mathbf{3}}$ & $\mathrm{Fe}_{\mathbf{2}} \mathbf{O}_{\mathbf{3}}$ & $\mathbf{M g O}$ & $\mathbf{C a O}$ & $\mathbf{K}_{\mathbf{2}} \mathbf{O}$ & Others & L.O.I \\
\hline DT & 57.11 & 3.17 & 4.97 & 20.60 & 2.68 & 0.23 & 0.25 & 9.91 \\
DC & 39.86 & 3.00 & 7.62 & 35.34 & 1.73 & 0.07 & 0.35 & 11.91 \\
\hline
\end{tabular}

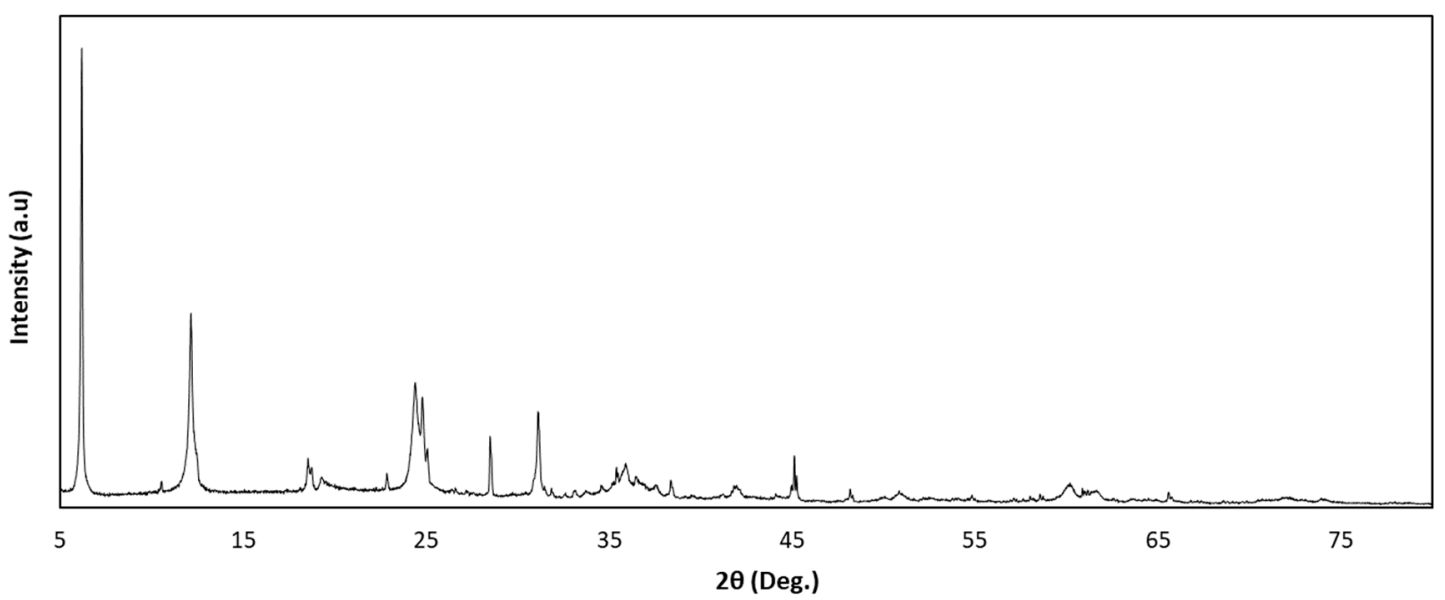

Figure 3. Diffraction (DRX) pattern of dunite-tailings. 


\subsection{Effects of the Amendments on the Physico-Chemical Properties of the Soil}

At the end of experiment, the WDT (brownfield-soil + dunite-tailings) and WDC (brownfield-soil + comminuted-dunite) treatments had significantly higher $\mathrm{pH}$ and conductivity values than untreated brownfield-soil (W) $(p<0.05)$. Although $\mathrm{W}$ had the highest values of TC (Table 3), the treatments did not show significant differences regarding this parameter $(p<0.05$, Table 4$)$. In addition, TN was not detectable in the W or in the WDT and WDC pots, while available $\mathrm{P}$ did not vary significantly. Remarkably, the cation exchange capacity (CEC) was significantly lower in W than in WDT and WDC pots $(p<0.05$, Table 4$)$.

Table 4. Physico-chemical properties of the untreated and treated brownfield soil after 75 days.

\begin{tabular}{|c|c|c|c|c|}
\hline Parameters & Units & $\mathbf{W}$ & WDT & WDC \\
\hline $\mathrm{pH}$ & & $7.99 \pm 0.11 b$ & $8.21 \pm 0.07 \mathrm{ab}$ & $8.37 \pm 0.14 a$ \\
\hline TC & \multirow{2}{*}{$\mathrm{mg} \cdot \mathrm{kg}^{-1}$} & $22.6 \pm 2.05 a$ & $18.5 \pm 1.17 \mathrm{~b}$ & $18.6 \pm 1.94 b$ \\
\hline TN & & $<\mathrm{DL}$ & $<\mathrm{DL}$ & $<\mathrm{DL}$ \\
\hline CEC & $\mathrm{cmol}_{(+)} \mathrm{kg}^{-1}$ & $4.99 \pm 0.15 b$ & $8.68 \pm 0.82 a$ & $8.52 \pm 0.80 a$ \\
\hline $\mathrm{Ca}$ & \multirow{5}{*}{$\mathrm{mg} \cdot \mathrm{kg}^{-1}$} & $447.9 \pm 13.0 \mathrm{a}$ & $392.29 \pm 29.5 \mathrm{ab}$ & $348.8 \pm 29.9 b$ \\
\hline K & & $22.50 \pm 1.38 \mathrm{a}$ & $43.76 \pm 5.22 b$ & $40.14 \pm 12.7 \mathrm{~b}$ \\
\hline Mg & & $13.76 \pm 0.09 b$ & $264.9 \pm 31.4 a$ & $281.3 \pm 28.8 a$ \\
\hline $\mathrm{Na}$ & & $14.75 \pm 1.79 a$ & $14.11 \pm 0.77 a$ & $15.25 \pm 2.95 a$ \\
\hline $\mathbf{P}$ & & $3.13 \pm 0.75 a$ & $2.00 \pm 0.52 a$ & $2.06 \pm 0.09 a$ \\
\hline
\end{tabular}

For each row, different letters in different samples means significant difference $(\mathrm{n}=3$, ANOVA; $p<0.05)$. $<\mathrm{DL}$ : below detection level. Typical deviation is represented by \pm .

Regarding cations, moderately significant changes were observed for $\mathrm{Ca}$ and $\mathrm{K}$, whereas no variation was observed for $\mathrm{Na}$. On the other hand, the abovementioned notable increase of CEC for the WDT and WDC pots was consistent with the marked increase in Mg observed $(p<0.05$, Table 4).

\subsection{Effects of the Amendments on Pollutants}

The pseudo-total concentrations of $\mathrm{As}, \mathrm{Cd}, \mathrm{Cu}, \mathrm{Pb}$ and $\mathrm{Zn}$ decreased (dilution effect mainly) with the addition of DT (WDT) and DC (WDC) to the polluted soil (W) (Table 5); in addition, comparison of the pseudo-total concentrations of four metalloids between treatments (WDT and WDC) revealed no significant differences $(p<0.05$, Table 5).

Table 5. Pseudo-total concentrations of $\mathrm{As}, \mathrm{Cd}, \mathrm{Cu}, \mathrm{Pb}$ and $\mathrm{Zn}$ of the untreated and treated brownfield soil.

\begin{tabular}{ccccc}
\hline Metal(oid)s & Units & W & WDT & WDC \\
\hline As & & $688.4 \pm 19.6 \mathrm{a}$ & $469.1 \pm 4.4 \mathrm{~b}$ & $497.0 \pm 34.7 \mathrm{~b}$ \\
$\mathbf{C d}$ & & $25.5 \pm 0.1 \mathrm{a}$ & $18.8 \pm 0.3 \mathrm{~b}$ & $19.3 \pm 1.3 \mathrm{~b}$ \\
$\mathbf{C u}$ & $\mathrm{mg} \cdot \mathrm{kg}^{-1}$ & $1953.5 \pm 2.37 \mathrm{a}$ & $1298.2 \pm 47.3 \mathrm{~b}$ & $1343.9 \pm 85.5 \mathrm{~b}$ \\
$\mathbf{P b}$ & & $5564.2 \pm 38.6 \mathrm{a}$ & $3881.3 \pm 152.6 \mathrm{~b}$ & $4051.8 \pm 175.6 \mathrm{~b}$ \\
$\mathbf{Z n}$ & & $3763.4 \pm 48.5 \mathrm{a}$ & $2679.4 \pm 43.0 \mathrm{~b}$ & $2781.6 \pm 137.3 \mathrm{~b}$ \\
\hline
\end{tabular}

For each row, different letters in different samples means significant difference ( $\mathrm{n}=3$, ANOVA; $p<0.05)$. Typical deviation is represented by \pm .

The available concentration of As showed no significant differences once the treatments were applied (Figure $4 \mathrm{~A}$ ), whereas the available concentrations of $\mathrm{Cd}, \mathrm{Cu}, \mathrm{Pb}$ and $\mathrm{Zn}$ decreased with respect to the polluted soil $(\mathrm{W})(p<0.05$, Figure $4 \mathrm{~A}-\mathrm{C})$, irrespective of the treatment used (DT or DC). 


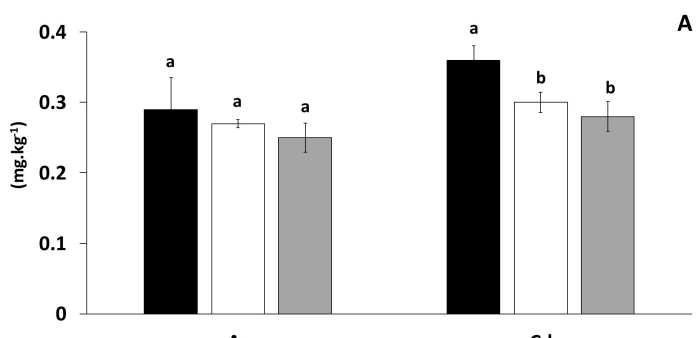

As

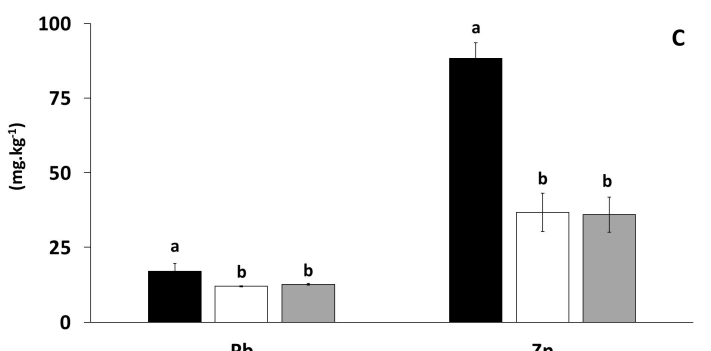

$\mathrm{Pb}$

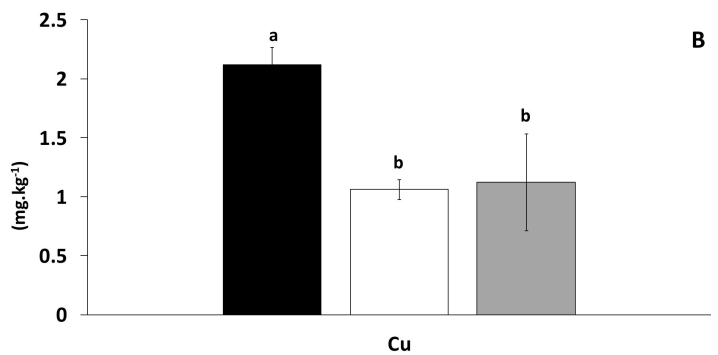

$\mathrm{Cu}$

- W $\square$ WDT $\square$ WDC

Figure 4. Influence of DC and DT on the available concentrations of $\mathrm{As}$ and $\mathrm{Cd}(\mathbf{A}), \mathrm{Cu}(\mathbf{B}), \mathrm{Pb}$ and $\mathrm{Zn}$ (C). For each row, different letters in different samples mean significant differences $(\mathrm{n}=3$, ANOVA; $p<0.05)$. Error bars represent standard deviation.

\subsection{Harvested Biomass of Brassica juncea L.}

The WDT and WDC treatments yielded a higher dry biomass of Brassica juncea L. than W (Figure 5; $p<0.05)$. This parameter was significantly higher in WDT than in WDC.

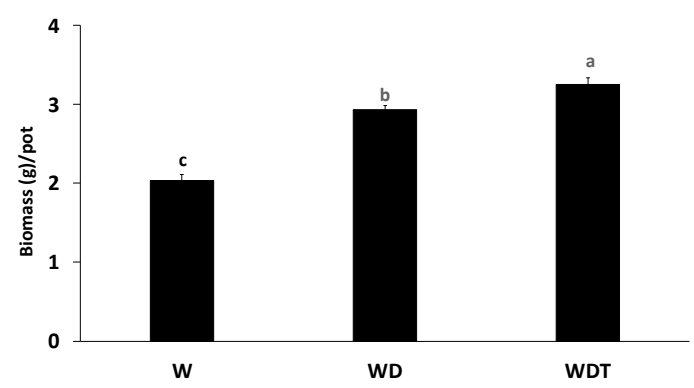

Figure 5. Harvested biomass of Brassica juncea L.

\section{Discussion}

The increase in soil pH after treatment of polluted soil with DT and DC was due to an increase in the concentration of $\mathrm{Mg}$ and, to a lesser extent, of $\mathrm{K}$. These increases improved the $\mathrm{CEC}$, which was correlated positively with the increase in $\mathrm{pH}(0.82, p>0.01)$. This upgrading can be explained by the high percentage of $\mathrm{Mg}$ in the dunite [27-29]. $\mathrm{Mg}$ was the element that increased most in response to treatments and it was also positively correlated with $\mathrm{pH}(0.83, p<0.01)$. In this context, an increase in CEC is relevant since correct soil CEC values indicate greater resistance to the chemical changes in a soil [30]. In fact, on the one hand, correct CEC values indicate good soil capacity to retain nutrients for plants [31]; on the other hand, CEC and $\mathrm{pH}$ are factors that play a crucial role in the availability of soil metals $[32,33]$. Therefore, an increase in the value of these factors will contribute to decreasing the available concentration of metals in the soil.

The decrease in TC values after the treatments is attributable to a dilution effect since DT and DC are inorganic amendments. Although significant differences in TC values were observed between the W, WDT and WDC treatments, according to [30], all three fall in a moderate category in terms of carbon content (average structural condition, average structural stability). 
The addition of DT and DC to the polluted soil did not increase the concentration of available As, in spite of the high pseudo-total concentration of this compound. This is a relevant observation because elevated As levels in soil and/or irrigation water can affect the growth and development of plants and could considerably increase dietary intake through plant-based items for consumption, thereby posing an additional threat to human health [34]. Availability of As generally increases as $\mathrm{pH}$ increases; however, in this case, the amendments increased the $\mathrm{pH}$ but did not enhance the available As concentrations. The negative effect of a $\mathrm{pH}$ higher than 7 on the increase of available As has already been reported [35,36]. In turn, another key factor in the mobilization and immobilization of As is the phosphorus $(\mathrm{P})$ concentration [37]. We found positive correlations between the concentrations of As and $\mathrm{P}(0.79, p<0.01)$. In our case, DT and DC had a lower concentration of $\mathrm{P}$ than $\mathrm{W}$. Therefore, the concentrations of $\mathrm{P}$ did not increase after application of the treatments, which would also explain the lack of an increase in As concentration.

$\mathrm{Cd}$ is particularly hazardous since it is easily taken up by plants and thus has a tendency to accumulate in food chain crops. Moreover, it is not degradable in nature and thus, once released into the environment, it will stay in circulation [38]. By increasing the $\mathrm{pH}$ and correcting the CEC, the amendments reduced the available $\mathrm{Cd}$. This capacity is reflected by significantly negative correlations between available $\mathrm{Cd}, \mathrm{pH}$ and CEC $(-0.82$ and -0.80 , respectively; $p<0.01)$. Other authors [39] have already shown that $\mathrm{pH}$ directly influences the availability of $\mathrm{Cd}$ in soil. Indeed, the $\mathrm{pH}$ value of the soil has a critical role in regulating the availability of metals. In this regard, the decrease in soil $\mathrm{pH}$ increases the mobility of the most labile elements in the soil, as is the case with $\mathrm{Cd}[32,33,40]$. Therefore, the increase in $\mathrm{pH}$ caused by the amendments made a significant contribution to reducing the available $\mathrm{Cd}$. Furthermore, the high concentration of $\mathrm{Mg}$ in the amendments promoted the retention of $\mathrm{Cd}$, which is corroborated by a considerably negative correlation $(-0.85 ; p<0.01)$.

As previously commented, $\mathrm{pH}$ and CEC play keys roles in metal solubility. In this regard, one of the metals most affected by these factors is $\mathrm{Cu}[41,42]$. Significantly negative correlations between the available $\mathrm{Cu}$ with respect to the $\mathrm{pH}, \mathrm{CEC}$ and $\mathrm{Mg}$ were found $(-0.81,-0.94$ and -0.95 , respectively; $p<0.01)$. This observation would explain the notable performance of the treatments with respect to reducing available $\mathrm{Cu}$ (average approximate decrease of $50 \%$ ).

$\mathrm{W}$ registered the highest available concentrations of $\mathrm{Pb}$ and $\mathrm{Zn}$. Treatments with DT and DC caused an increase in $\mathrm{pH}$, thereby reducing these concentrations, as occurred with $\mathrm{Cd}$. These results are consistent with the predictions made in previous work [42]. In our case, a significant negative correlation between the $\mathrm{pH}$ and the concentrations of $\mathrm{Pb}$ and $\mathrm{Zn}(-0.70$ and -0.79 , respectively; $p<0.05)$ was observed. The correction of the CEC was also favorable to achieve these results, since an increase in the concentration of basic cations enhances the fixation of metals. In fact, significant negative correlations were also obtained between the CEC and the available $\mathrm{Pb}$ and $\mathrm{Zn}(-0.78, p<0.05$ and 0.95 , $p<0.01$, respectively). A significant negative correlation was also determined between $\mathrm{Mg}$ vs. $\mathrm{Zn}$ and $\mathrm{Pb}(-0.99$ and -0.79 , respectively; $p<0.01)$.

The correction of the $\mathrm{pH}$ and CEC values, together with the decrease in the available concentrations of $\mathrm{Cd}, \mathrm{Cu}, \mathrm{Pb}$ and $\mathrm{Zn}$, caused an increase in the biomass of Brassica juncea L. Initially, the increase in $\mathrm{pH}$ and CEC in this experiment showed a significant positive correlation with the increase in biomass $(-0.81$ and 0.89 , respectively; $p<0.01)$ [43]. The treatment with DC was the most effective in enhancing biomass, possibly because it was the amendment that promoted the greatest increase in $\mathrm{pH}$. In addition, DC was also the treatment that yielded a high increase in $\mathrm{Mg}$ concentration, which was positively correlated with the biomass $(0.95, p<0.01)$. Furthermore, both amendments reduced $\mathrm{Cd}, \mathrm{Cu}, \mathrm{Pb}$ and $\mathrm{Zn}$ availability, thereby favoring an increase in Brassica biomass [44]. A significant negative correlation was observed between the biomass and the available $\mathrm{Cd}, \mathrm{Cu}, \mathrm{Pb}$ and $\mathrm{Zn}(-0.81,-0.84, p<0.01 ;-0.74$, $p<0.05$; respectively). 


\section{Conclusions}

Here we addressed the reuse of waste and a subproduct from a dunite mine for the remediation of a soil affected by multi-element pollution. These materials had similar effects on available metal(oid) concentrations and on the edaphic properties of the soil. Irrespective of the dunite product used (tailings or comminuted), $\mathrm{Zn}$ was immobilized, probably due to the increase in $\mathrm{pH}$ and the contribution of $\mathrm{Mg}$. Regarding $\mathrm{Cd}, \mathrm{Cu}$ and $\mathrm{Pb}$, the immobilization was moderately significant, but for As, the available concentrations were not modified. Regarding edaphic properties, the increase in $\mathrm{Mg}$ concentration influenced the CEC, resulting in enhanced soil properties. The amendments led to the immobilization of the metals and an increase in CEC, thereby reducing phytotoxicity and increasing harvested biomass. Given that mining activities produce a greater amount of DT than DC, the field application of the former, following the circular economy model, may offer a promising approach to promote its reuse in soil remediation strategies.

On the basis of our findings, dunite mining waste and subproducts emerge as new materials useful for stabilization of polluted soils. However, although the laboratory study has revealed good results, field-scale studies should be carried out in order to address a better understanding of the potential effectiveness of these amendments, and to identify possible difficulties that could occur (such as long-term modifications in the pollutant availability levels). Overall, future studies involving different soils, conditions, and doses are required in order to corroborate these promising results.

Author Contributions: Conceptualization, J.L.R.G.; Resources, M.C.M., P.D.G., J.M.R. and J.J.Á.R.; Supervision, R.F. and J.M.M.A.; Writing-original draft, D.B.

Funding: Diego Baragaño obtained a grant from the "Formación del Profesorado Universitario" program, financed by the "Ministerio de Educación, Cultura y Deporte de España".

Conflicts of Interest: The authors declare no conflict of interest.

\section{References}

1. Fisher, L.V.; Barron, A.R. The recycling and reuse of steelmaking slags-A review. Resour. Conserv. Recycl. 2019, 146, 244-255. [CrossRef]

2. Jiang, Y.; Ling, T.C.; Mo, K.H.; Shi, C. A critical review of waste glass powder-Multiple roles of utilization in cement-based materials and construction products. J. Environ. Manag. 2019, 242, 440-449. [CrossRef] [PubMed]

3. Millar, N.; McLaughlin, E.; Börger, T. The Circular Economy: Swings and Roundabouts? Ecol. Econ. 2019, 158, 11-19. [CrossRef]

4. Rees, W. What's blocking sustainability? Human nature, cognition, and denial. Sustain. Sci. Pract. Policy 2010, 6, 13-25. [CrossRef]

5. Vlek, C.; Steg, L. Human behavior and environmental sustainability: Problems, driving forces and research topics. J. Soc. Issues 2007, 63, 1-19. [CrossRef]

6. European Commission. EU SCIENCE HUB. The European Commission's Science and Knowledge Service. Available online: https://ec.europa.eu/jrc/en/research-topic/waste-and-recycling (accessed on 5 July 2019).

7. European Commission. Circular Economy. Closing the Loop. An Ambitious EU Circular Economy Package. 2019. Available online: http://ec.europa.eu/environment/circular-economy/index_en.htm (accessed on 5 July 2019).

8. Velenturf, A.P.M.; Archer, S.A.; Gomes, H.I.; Christgen, B.; Lag-Brotons, J.; Purnell, P. Circular economy and the matter of integrated resources. Sci. Total Environ. 2019, 689, 963-969. [CrossRef] [PubMed]

9. Hudson-Edwards, K.A.; Jamieson, H.E.; Lottermoser, B.G. Mine wastes: Past, present, future. Elements 2011, 7, 375-380. [CrossRef]

10. Capasso, I.; Lirer, S.; Flora, A.; Ferone, C.; Cioffi, R.; Caputo, D.; Liguori, B. Reuse of mining waste as aggregates in fly ash-based geopolymers. J. Clean Prod. 2019, 220, 65-73. [CrossRef]

11. González-Fernández, B.; Rodríguez-Valdés, E.; Boente, C.; Menéndez-Casares, E.; Fernández-Braña, A.; Gallego, J.R. Long-term ongoing impact of arsenic contamination on the environmental compartments of a former mining-metallurgy area. Sci. Total Environ. 2018, 610-611, 820-830. [CrossRef] 
12. Clemente, R.; Arco-Lázaro, E.; Pardo, T.; Martín, I.; Sánchez-Guerrero, A.; Sevilla, F.; Bernal, M.P. Combination of soil organic and inorganic amendments helps plants overcome trace element induced oxidative stress and allows phytostabilisation. Chemosphere 2019, 223, 23-231. [CrossRef]

13. Delil, A.D.; Köleli, N. Investigation of a combined continuous flow system for the removal of $\mathrm{Pb}$ and $\mathrm{Cd}$ from heavily contaminated soil. Chemosphere 2019, 229, 181-187. [CrossRef] [PubMed]

14. Demir, A.; Pamukcu, S.; Shrestha, R.A. Simultaneous removal of $\mathrm{Pb}, \mathrm{Cd}$, and $\mathrm{Zn}$ from heavily contaminated mine tailing soil using enhanced electrochemical process. Environ. Eng. Sci. 2015, 32, 416-424. [CrossRef]

15. Mendez, M.O.; Maier, R.M. Phytostabilization of mine tailings in arid and semiarid environments-An emerging remediation technology. Environ. Health Perspect. 2008, 116, 278-283. [CrossRef] [PubMed]

16. Bolan, N.; Kunhikrishnan, A.; Thangarajan, R.; Kumpiene, J.; Parke, J.; Makino, T.; Kirkham, M.B.; Shceckel, K. Remediation of heavy metal(loid)s contaminated soils-To mobilize or to immobilize? J. Hazard. Mater. 2014, 266, 141-166. [CrossRef] [PubMed]

17. Kumpiene, J.; Lagerkvist, A.; Maurice, C. Stabilization of $\mathrm{As}, \mathrm{Cr}, \mathrm{Cu}, \mathrm{Pb}$ and $\mathrm{Zn}$ in soil using amendments-A review. Waste Manag. 2008, 28, 215-225. [CrossRef] [PubMed]

18. Del Valle-Zermeño, R.; Giro-Paloma, J.; Formosa, J.; Chimenos, J.M. Low-grade magnesium oxide by-products for environmental solutions: Characterization and geochemical performance. J. Geochem. Explor. 2015, 152, 134-144. [CrossRef]

19. Kayser, C.; Larkin, T.; Singhal, N. Amendment of biosolids with waste materials and lime: Effect on geoenvironmental properties and leachate production. Waste Manag. 2015, 46, 165-175. [CrossRef] [PubMed]

20. Porta, J.; Loópez-Acevedo, M.; Rodriíguez, R. Técnicas y Experimentos en Edafología; Collegi Oficial D’Enginyers Agronoms de Catalunya: Barcelona, Spain, 1986.

21. Hendershot, W.H.; Duquette, M. A simple barium chloride method for determining cation exchange capacity and exchangeable cations. Soil Sci. Soc. Am J. 1986, 50, 605-608. [CrossRef]

22. Houba, V.J.G.; Temminghoff, E.J.M.; Gaikhorst, G.A.; VanVark, W. Soil analysis procedures using 0,01M calcium chloride as extraction reagent. Commun. Soil Sci. Plant Anal. 2000, 3, 1299-1396. [CrossRef]

23. Mehlich, A. Mehlich 3 soil test extractant: A modification of Mehlich 2 extractant. Commun. Soil Sci. Plant Anal. 2008, 15, 1409-1416. [CrossRef]

24. Rollinson, H. Dunites in the mantle section of the Oman ophiolite-The boninite connection. Lithos 2019, 334-335, 1-7. [CrossRef]

25. Abily, B.; Geuleneer, G. The dunitic mantle-crust transition zone in the Oman ophiolite: Residue of melt-rock interaction, cumulates from high-MgO melts or both? Geology 2013, 41, 67-70. [CrossRef]

26. Caballero, R.; García-Arias, M.; Rubio, L.; Corretgé, L.G. Dunite-A cost effective raw material in basic refractory mixes for Steel making. In Proceedings of the 52nd International Colloquium on Refractories, EUROGRESS, Aachen, Germany, 23-24 September 2009.

27. Lessovaia, S.; Dultz, S.; Polekhovsky, Y.; Krupskaya, Y.; Vigasina, M.; Melchakova, L. Rock control of pedogenic clay mineral formation in a shallow soil from serpentinous dunite in the Polar Urals, Russia. Appl. Clay Sci. 2012, 64, 4-11. [CrossRef]

28. Lessovaia, S.; Dultz, S.; Plötze, M.; Andreeva, N.; Polekhovsky, Y.; Filimonov, A.; Momotova, O. Soil development on basic and ultrabasic rocks in cold environments of Russia traced by mineralogical composition and pore space characteristics. Catena 2016, 137, 596-604. [CrossRef]

29. Van Noort, R.; Mørkved, P.T.; Dundas, S.H. Acid neutralization by mining waste dissolution under conditions relevant for agricultural applications. Geosciences 2018, 8, 380. [CrossRef]

30. Hazelton, P.; Murphy, B. Interpreting Soils Test Resulting. What Do All the Numbers Mean? CSIRO: Collingwood, VIC, Australia, 2007.

31. Brewer, C.E.; Urger, U.; Schmidt-Rohr, K.; Brown, R.C. Criteria to Select Biochars for Field Studies based on Biochar Chemical Properties. BioEnergy Res. 2011, 4, 312-323. [CrossRef]

32. Park, J.H.; Choppala, G.K.; Bolan, N.S.; Chung, J.W.; Chuasavathi, T. Biochar reduces the bioavailability and phytotoxicity of heavy metals. Plant Soil. 2011, 348, 439-451. [CrossRef]

33. Weng, L.; Temminghoff, E.J.M.; Van Riemsdijk, W.H. Contribution of individual sorbents to the control of heavy metal activity in sandy soil. Int. J. Environ. Sci. Technol. 2001, 35, 4436-4443. [CrossRef]

34. Brammer, H.; Ravenscroft, P. Arsenic in groundwater: A threat to sustainable agriculture in South and South-east Asia. Environ. Int. 2009, 35, 647-654. [CrossRef]

35. O'Neill, P. Arsenic. In Heavy Metals in Soils; Alloway, B.J., Ed.; Blackie: London, UK, 1990; pp. 83-99. 
36. Fitz, W.J.; Wenzel, W.W. Arsenic transformations in the soil-rhizosphere-plant system: Fundamentals and potential application to phytoremediation. J. Biotechnol. 2002, 99, 259-278. [CrossRef]

37. Yan, X.P.; Kerrich, R.; Hendry, M.J. Distribution of arsenic(III), arsenic(V) and total inorganic arsenic in pore waters from a thick till and clay-rich aquitard sequence, Saskatchewan, Canada. Geochim. Cosmochim. Acta 2000, 62, 2637-2648. [CrossRef]

38. Dudka, S.; Adriano, D.C. Environmental impacts of metal ore mining and processing: A review. J. Environ. Qual. 1997, 26, 590-602. [CrossRef]

39. Beesley, L.; Moreno-Jimenez, E.; Clemente, R.; Lepp, N.; Dickinson, N. Mobility of arsenic, cadmium and zinc in a multi-element contaminated soil profile assessed by in-situ soil pore water sampling, column leaching and sequential extraction. Environ. Pollut. 2010, 158, 155-160. [CrossRef]

40. Smith, S.R. A critical review of the bioavailability and impacts of heavy metals in municipal solid waste composts compared to sewage sludge. Environ. Int. 2009, 35, 142-156. [CrossRef] [PubMed]

41. Forján, R.; Asensio, V.; Rodríguez-Vila, A.; Covelo, E.F. Contribution of waste and biochar amendment to the sorption of metals in a copper mine tailing. Catena 2016, 137, 120-125.

42. Rieuwerts, J.; Ashmore, M.; Farago, M.; Thornton, I. The influence of soil characteristics on the extractability of $\mathrm{Cd}, \mathrm{Pb}$ and $\mathrm{Zn}$ in upland and moorland soils. Sci. Total Environ. 2006, 366, 864-875. [CrossRef]

43. Forján, R.; Rodríguez-Vila, R.; Cerqueira, B.; Covelo, E.F.; Marcet, P.; Asensio, V. Comparative effect of compost and technosol enhanced with biochar on the fertility of a degraded soil. Environ. Monit. Assess. 2018, 190, 610.

44. Rodríguez-Vila, A.; Forján, R.; Guedes, R.S.F.; Covelo, E. Changes on the Phytoavailability of Nutrients in a Mine Soil Reclaimed with Compost and Biochar. Water Air Soil Pollut. 2016, 227, 453. [CrossRef]

(C) 2019 by the authors. Licensee MDPI, Basel, Switzerland. This article is an open access article distributed under the terms and conditions of the Creative Commons Attribution (CC BY) license (http://creativecommons.org/licenses/by/4.0/). 